\title{
OPEN ACCESS \\ Movements of subadult prickly sharks Echinorhinus cookei in the Monterey Canyon
}

\author{
Cyndi L. Dawson ${ }^{1, *}$, Richard M. Starr ${ }^{2}$ \\ ${ }^{1}$ Moss Landing Marine Laboratories, and ${ }^{2}$ University of California Sea Grant Extension Program, \\ Moss Landing Marine Laboratories, 8272 Moss Landing Road, Moss Landing, California 95039, USA
}

\begin{abstract}
The prickly shark Echinorhinus cookei is a poorly known predatory shark that occurs in the Monterey Canyon, USA. Between March 2005 and September 2006, 15 subadult prickly sharks (170 to $270 \mathrm{~cm}$ total length) were tagged with acoustic transmitters and tracked to determine their site fidelity, home range, habitat use, rates of movement, and diel activity. An array of moored receivers extending $3.5 \mathrm{~km}$ offshore from the apex of the Monterey Canyon recorded the occurrence of 8 sharks tagged with coded transmitters for 400 to $561 \mathrm{~d}$. Four sharks were tagged with continuous transmitters and monitored by a moored receiver that recorded date, time, and depth for 123 to $212 \mathrm{~d}$. Three sharks were tagged with archival transmitters that were monitored by a 2-way communicating moored receiver. One female and 2 males tagged with continuous transmitters were also tracked manually from a surface vessel for $61.0,51.8$ and $62.8 \mathrm{~h}$, respectively, over a period of 64 to $71 \mathrm{~d}$. Home ranges for these sharks were $0.20,2.20$, and $1.46 \mathrm{~km}^{2}$. All tagged sharks showed a high degree of site fidelity to the study area and demonstrated pronounced diel movements, moving along the axis of the canyon offshore to discrete areas during the day and inshore at night. Sharks were sedentary during the day and actively swam in the water column at night and were most active during crepuscular and nighttime periods.
\end{abstract}

KEY WORDS: Diel movements - Submarine canyon • Prickly shark • Acoustic telemetry · Echinorhinus cookei

Resale or republication not permitted without written consent of the publisher

\section{INTRODUCTION}

Ecosystem-based management (EBM) is increasingly recommended as a strategy for managing marine resources (McLeod et al. 2005, Magnuson et al. 2006). A tenet of EBM is the importance of identifying and understanding the factors which influence the structure of an ecosystem (Magnuson et al. 2006). Apex predators are shown to be critical determinants of the structure and function of ecosystems (e.g. Estes et al. 1998, Carr et al. 2002, Shears \& Babcock 2002, Bascompte et al. 2005, Reisewitz et al. 2006, Crowder \& Norse 2008). Moreover, apex predators have large cascading effects on ecosystems (Myers et al. 2007, Zeidberg \& Robison 2007), thus a comprehensive understanding of the spatial ecology of large predators is essential for successful implementation of EBM. A first step in describing the role of an apex predator in an ecosystem is to obtain knowledge of a predator's habitat use and movement patterns, which is fundamental for understanding its life history and ecology (Andrew \& Mapstone 1987, Zeller 1997).

The prickly shark Echinorhinus cookei is a large predatory shark with a pan-Pacific distribution (Ebert 2003). Prickly sharks are uncommon deep-water sharks, and few published reports describe their natural history (Compagno 1984, Ebert 2003). Prickly sharks have been captured in depths ranging from 11 to $650 \mathrm{~m}$, and possibly as great as $1000 \mathrm{~m}$ (Compagno 1984, Kobayashi 1986, Melendez \& Menses 1986). Sexual maturity occurs at $290 \mathrm{~cm}$ total length (TL) for females and $240 \mathrm{~cm}$ TL for males (Compagno 1984). Based on limited published stomach content analyses, the prickly shark's diet consists of small sharks, egg 
cases of other sharks and rays, octopus, squid, chimera, and other mid-water and benthic fishes (Pietschmann 1930, Garrick 1960, Garrick \& Moreland 1968, Varoujean 1972, Crow et al. 1996). Most catches or observations of prickly sharks have been in deep water $(>100 \mathrm{~m})$, but they have been reported to occur in shallow water at the head of the Monterey Canyon near Moss Landing, California, USA (Varoujean 1972, Anderson et al. 1979). Crane \& Heine (1992) observed aggregations (>30 sharks) of prickly sharks in waters $<40$ m deep during monthly SCUBA surveys conducted between June 1990 and September 1991.

The occurrence of large numbers of prickly sharks in the upper reaches of the Monterey Canyon provided a unique opportunity to learn more about a large shark in the Monterey Canyon ecosystem. We used a combination of 3 acoustic telemetry techniques (i.e. use of acoustic monitors, manual tracking, and communicating archival tags) to track the movements of prickly sharks. In the present study we provide estimates of site fidelity, home range, habitat use, rates of movement, and diel activity patterns of prickly sharks that differ from those previously reported. These results include the first archival data recorded for a prickly shark.

\section{METHODS}

Study site. The Monterey Canyon is a large submarine canyon located in the middle of Monterey Bay, adjacent to Moss Landing, California, USA (Fig. 1). The apex (head) of the Monterey Canyon is located approximately $300 \mathrm{~m}$ due west of Moss Landing $\left(36^{\circ} 48^{\prime} 3^{\prime \prime} \mathrm{N}, 121^{\circ} 47^{\prime} 22^{\prime \prime} \mathrm{W}\right)$. Benthic habitats at the head of the canyon are almost all comprised of steep sediment slopes or sediment-filled channels (Smith et al. 2007). Mid-water habitats are characterized by dynamic currents and a high level of particulate matter resulting from longshore transport and freshwater flow into the area. We defined 4 habitat zones within the study area: (1) inshore benthic habitats 0 to $5 \mathrm{~m}$ above the seafloor at the head of the canyon in waters less than $100 \mathrm{~m}$ deep (Inshore-benthic, $\left.I_{B}\right)$, (2) the water column $>5 \mathrm{~m}$ above the seafloor at the head of the canyon (Inshore-midwater, $I_{M}$ ), (3) offshore benthic habitats 0 to $5 \mathrm{~m}$ above the seafloor in waters greater than $100 \mathrm{~m}$ deep (Offshore-benthic, $\mathrm{O}_{\mathrm{B}}$ ), and (4) the water column $>5 \mathrm{~m}$ above the seafloor in the offshore area (Offshoremidwater, $\left.\mathrm{O}_{\mathrm{M}}\right)$.

Capture, tagging, and tracking. Prickly sharks were captured by deploying 5 baited lines at the head of the canyon in 30 to $65 \mathrm{~m}$ of water at flood tides during the day or night. Baited lines were set out for 45 to $50 \mathrm{~min}$ in the axis of the canyon. Each line contained two 16/0 barbed circle-hooks baited with salmon Oncorhynchus tshawytscha fillets and placed 1 and $5 \mathrm{~m}$ above the bottom. Vinyl tubing covered the bottom $6 \mathrm{~m}$ of line to prevent hooked sharks from wrapping in the line and injuring themselves. Captured sharks were brought to the surface by hand and maneuvered into a $2 \mathrm{~m}$ long nylon stretcher along the side of the boat. Each shark was placed ventral side up in the stretcher, making its body cavity accessible for surgical implantation of tags.

Immediately after securing a shark to the side of the boat, a small incision just larger than the diameter of the transmitters was made in the shark's ventral surface, anterior to the pelvic fins and near the ventral mid-line. The transmitters were gently pushed through the incision which was then closed with interrupted monofilament sutures. All surgical instruments and transmitters were bathed in an antiseptic iodine solution before surgery. After surgery was complete, the shark was rolled onto its ventral surface and an external dart tag was inserted in the dorsal musculature, just anterior to the first dorsal fin. Total length of each shark was recorded and skin samples $\left(0.25 \mathrm{~cm}^{2}\right)$ were collected for future stable isotope and DNA analyses. After all data were collected, the boat was driven forward slowly to run water over the shark's gills. When the shark began to exhibit spontaneous tail movements, it was released at the approximate location of capture. Time from capture to release was less than 20 min for all sharks.

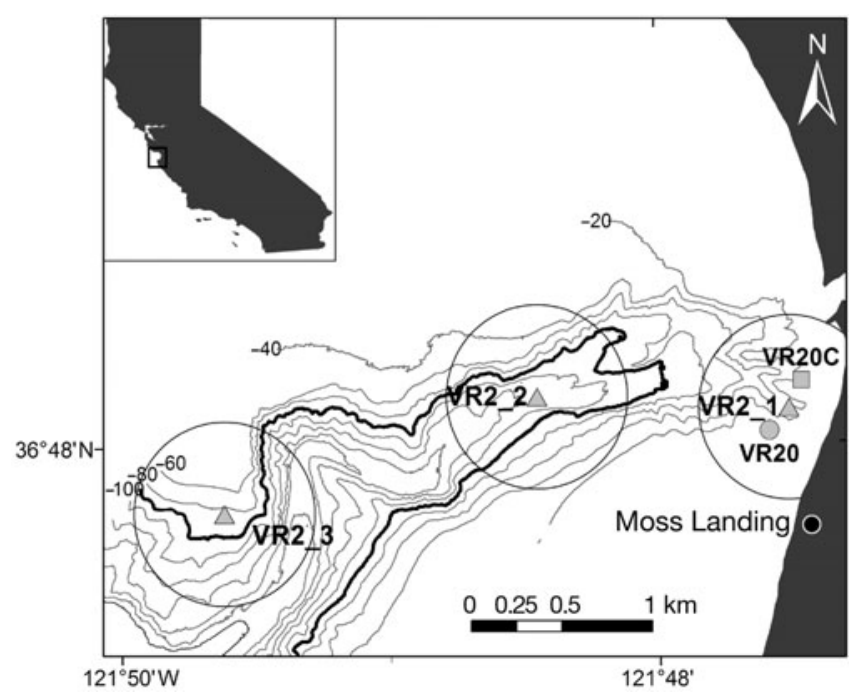

Fig. 1. Study area with detail of the upper reaches of the Monterey Canyon, located adjacent to Moss Landing, California, USA. The receiving array included 3 VR2, 1 VR20, and 1 VR20C receiver. The tested receiving range for the VR2s is shown as a $500 \mathrm{~m}$ buffer around each VR2 receiver. Isobaths = $20 \mathrm{~m}$ increments. Thick dark line = boundary between inshore and offshore habitats (100 m isobath) 
One of 3 types of transmitters were implanted into each shark: (1) coded V16, (2) continuous V16P, or (3) archival CHAT transmitters (Vemco) (Table 1). The V16 coded tags (16 mm diam. $\times 92 \mathrm{~mm}$; 8 sharks) transmitted an ID code with date and time on a frequency of $69 \mathrm{kHz}$. Predicted battery life of 5 of these tags was $439 \mathrm{~d}$, and battery life of the other 3 was estimated to be $1442 \mathrm{~d}$. Signals from coded tags were recorded by 3 Vemco VR2 receivers moored in the axis of the canyon (Fig. 1). The VR2 receiver closest to shore (VR2_1) was deployed approximately $300 \mathrm{~m}$ from shore on a mooring with a surface float in $30 \mathrm{~m}$ of water (Fig. 1). Two additional VR2 receivers were moored with subsurface floats in the axis of the canyon in $80 \mathrm{~m}$ (VR2_2) and $130 \mathrm{~m}$ (VR2_3) of water at a distance of 1.5 and $3.5 \mathrm{~km}$ offshore, respectively (Fig. 1). Results of field tests indicated that the receiving range of the moored VR2 receivers was $500 \mathrm{~m}$. These VR2 receivers were recovered using Benthos Model 875 acoustic releases and downloaded at least every $85 \mathrm{~d}$. Although the mooring lines for the longer deployments were fouled with some invertebrate growth, the VR2 receivers themselves were almost completely free from all growth and it is unlikely that bio-fouling affected their receiving range.

Table 1. Echinorhinus cookei. Number of days that 15 subadult prickly sharks were tracked in the Monterey Canyon using acoustic telemetry techniques (see 'Materials and methods - Capture, tagging and tracking' for description of Vemco transmitters and monitoring types). 'Monitored' $=$ no. of days receivers were monitoring signals during the study period; 'Time at liberty' $=$ no. of days between date of release and last detection of a shark by a monitor; TL = total length. Days monitored reflect the actual days monitoring took place and time at liberty was sequential from the release date and last date a shark was heard by a monitor, regardless of the monitoring status between dates

\begin{tabular}{|cccccc|}
$\begin{array}{l}\text { Tag type } \\
\text { and shark }\end{array}$ & TL $(\mathrm{cm})$ & Sex & $\begin{array}{c}\text { Date released } \\
(\mathrm{mm} / \mathrm{dd} / \mathrm{yy})\end{array}$ & $\begin{array}{c}\text { Monitored } \\
\text { (d) }\end{array}$ & $\begin{array}{c}\text { Time at } \\
\text { liberty (d) }\end{array}$ \\
\hline V16 (coded) & & & & & \\
1 & 217 & $\mathrm{~F}$ & $03 / 01 / 05$ & 561 & 512 \\
2 & 225 & $\mathrm{~F}$ & $03 / 12 / 05$ & 550 & 544 \\
3 & 190 & $\mathrm{~F}$ & $05 / 12 / 05$ & 489 & 459 \\
4 & 184 & $\mathrm{~F}$ & $05 / 12 / 05$ & 489 & 460 \\
5 & 176 & $\mathrm{M}$ & $06 / 24 / 05$ & 446 & 419 \\
6 & 170 & $\mathrm{M}$ & $07 / 27 / 05$ & 413 & 405 \\
7 & 200 & $\mathrm{M}$ & $07 / 28 / 05$ & 412 & 382 \\
8 & 175 & $\mathrm{~F}$ & $08 / 09 / 05$ & 400 & 367 \\
V16P (continous) & & & & & \\
9 & 250 & $\mathrm{~F}$ & $05 / 13 / 05$ & 212 & 102 \\
10 & 220 & $\mathrm{~F}$ & $08 / 10 / 05$ & 123 & 122 \\
11 & 178 & $\mathrm{M}$ & $08 / 10 / 05$ & 123 & 123 \\
12 & 184 & $\mathrm{M}$ & $08 / 10 / 05$ & 123 & 120 \\
CHAT (archival) & & & & \\
13 & 270 & $\mathrm{~F}$ & $07 / 26 / 05$ & 98 & 17 \\
14 & 225 & $\mathrm{~F}$ & $07 / 27 / 05$ & 98 & 29 \\
15 & 198 & $\mathrm{~F}$ & $08 / 09 / 05$ & 98 & 10 \\
\hline
\end{tabular}

The V16P tags (4 sharks) continuously transmitted ID codes and depths on unique frequencies $(54,63,75$, or $78 \mathrm{kHz}$ ). The estimated battery life of the 4 tags was 95 d. Data was collected from these transmitters by manually tracking tagged sharks from a surface vessel using a Vemco V10 directional hydrophone and Vemco VR60 receiver. Field tests indicated that the receiving range of the VR60 receiver and hydrophone was 100 to $200 \mathrm{~m}$. Data was also collected from the V16P transmitters by using a moored Vemco VR20 receiver that sequentially scanned each of the frequencies for $1 \mathrm{~min}$ and recorded signals present in the area. This enabled us to collect data from the continuous transmitters at times other than when we were manually tracking. The VR20 receiving range was determine post-hoc by comparing the maximum depths recorded with the surrounding bathymetry, and was estimated at 700 to $900 \mathrm{~m}$. The VR20 receiver was moored at the head of the canyon near the VR2_1 receiver and downloaded every $30 \mathrm{~d}$.

A $10 \mathrm{~m}$ long boat was used to manually track 3 of the 4 sharks tagged with continuous transmitters for nonconsecutive $6 \mathrm{~h}$ blocks of time (00:00-06:00 h, 06:0012:00 h, 12:00-18:00 h, and 18:00-00:00 h). Each shark was tracked at least once in each block of time, over a period of 64 to $71 \mathrm{~d}$, to ensure that a representative sample of activity patterns was recorded at all times of day. Once a shark was detected in a tracking period, it was tracked continuously for the rest of the $6 \mathrm{~h}$ time period. Towards the end of the battery life of the continuous transmitters, tracking blocks were reapportioned to focus on crepuscular periods (02:00 to 08:00 and $16: 00$ to $22: 00 \mathrm{~h})$. The ArcNav extension (Hatcher 1997) for Arcview GIS Version 3.2 software was used to record GPS positions of the tracking vessel on a laptop in real time as sharks were tracked. A positional 'fix' on each shark was established at least every $10 \mathrm{~min}$ by rotating the V10 directional hydrophone slowly $360^{\circ}$ and recording the GPS position when no degradation in the acoustic signal strength was detected.

Vemco VX32TP Communicating History Acoustic Transponder (CHAT) archival tags (32 mm diam. $\times 150 \mathrm{~mm}$ ) were implanted in 3 sharks. The CHAT tags were programmed to record depth every $10 \mathrm{~min}$; depth recordings were averaged hourly and stored to the CHAT tag memory. Through 2-way communication occurring at a frequency of $32.8 \mathrm{kHz}$, the data stored in memory were transferred to a VR20C receiver when the tagged shark was in range of the receiver. The range of the VR20C 
receiver was not tested, but we believe it was similar to the range of the VR20 receiver. The VR20C receiver was also moored at the head of the canyon and downloaded every $30 \mathrm{~d}$. The estimated battery life of each CHAT tag was $365 \mathrm{~d}$.

Data analysis. The 3 types of tags each provided different types of information. The coded tags implanted in 8 sharks were used to estimate the temporal frequency and time of occurrence of prickly sharks in the study area. Three VR2 receivers were lost during the study period. However, there was always at least one VR2 receiver deployed throughout the study period. During the 2 time periods when all 3 receivers were in place (10 Oct 2005 to 12 Feb 2006 and 15 June to 12 Sept 2006), detections from all receivers were combined and separated by time of day (Dawn and Day: 06:00 to 17:30 h, Dusk and Night: 17:30 to 06:00 h) to determine the diel spatial distribution of prickly sharks.

Home range, habitats occupied, movement rates and diel pattern of prickly sharks were estimated using the continuous transmitters placed in 4 sharks. Hawth's spatial analysis tools (Beyer 2004) for ArcGIS was used to determine the habitats most frequently used. The Hawth analysis tools extension provided the number of positional fixes encompassed within the boundaries of each habitat and time of day that we identified. A kernel utilization distribution (KUD; Worton 1987, 1989) was also calculated for each shark tracked manually. The KUD is a graphical depiction of the likelihood of being found within a discrete area during a particular time period. Positional data for all time periods for each shark were pooled and KUDs calculated at 90, 75, and $50 \%$ probability levels. Home range was defined as the sum of the areas encompassing the 90, 75, and $50 \%$ KUDs.

In addition to estimates of the spatial and temporal distribution of prickly sharks, the continuous transmitters enabled us to evaluate rates of vertical and horizontal movements. We calculated the difference between the mean depth of a tagged shark in each hour of the day and that shark's mean daily depth (i.e. we calculated a depth anomaly), and then averaged the depth anomalies of all sharks for each hour to evaluate the variability of diel activity patterns among the 4 sharks tagged with continuous transmitters. The mean depth for each hour was calculated by pooling and averaging all data collected from a shark for a given hour of the day. The mean rate of movement (ROM) for sharks carrying continuous transmitters was also calculated by measuring the distance between 2 successive GPS fixes and dividing it by the elapsed time between the 2 points. ROM is reported for 4 diel periods (Dawn $=06: 00$ to 08:00 h, Day $=08: 00$ to $17: 30 \mathrm{~h}$, Dusk $=17: 30$ to $19: 30 \mathrm{~h}$, and Night $=19: 30$ to $06: 00 \mathrm{~h}$ ).
The 3 CHAT tags provided a continuous record of the depth (and thus vertical movements) of tagged prickly sharks. Average hourly depths for all data obtained from CHAT tags was calculated and plotted. Significant differences in mean depths between day and night periods were determined using a 2-sample $t$ test. The day, night, and crepuscular time periods were based on the times of sunrise and sunset when the data were collected.

\section{RESULTS}

\section{Capture, tagging, and tracking}

Twenty-six prickly sharks were caught between February and August 2005 (not all sharks hooked were landed and tagged). Fishing occurred during the day between February and April 2005, and average \pm SE catch-per-unit-effort (CPUE, calculated by taking the total time all lines were in the water [i.e. soak time] divided by the number of prickly sharks caught) was $0.06 \pm 0.24$ sharks $^{-1}$. Initial data collected from sharks tagged in spring 2005 indicated that tagged individuals were more consistently located offshore during the day, thus we fished at night between May and August 2005. At night, average CPUE increased more than tenfold to $0.71 \pm 0.21$ sharks $\mathrm{h}^{-1}$. Sharks resisted capture more actively and were more restless during the tagging procedures at night than during day. Males did not occur in the catch until June, and females dominated the catch until late July when the sex ratio of catches became close to 1.0 .

Fifteen prickly sharks were tagged and tracked between March 2005 and September 2006 (Table 1). The 10 females (TL 175 to $270 \mathrm{~cm}$ ) were significantly (Student's $t=2.42, \mathrm{p}=0.031$ ) larger in size than the 5 males (TL 170 to $200 \mathrm{~cm}$ ) and all sharks were smaller than the reported size at maturity. All sharks survived surgery and swam away in apparently good condition. Signals from all tagged sharks, excluding the 3 sharks tagged with CHAT tags (Sharks 13 to 15), were detected throughout the study period, or for the duration of the transmitter's battery life (see 'Time at Liberty' in Table 1).

The 5 female and 3 male sharks tagged with coded transmitters (Sharks 1 to 8 ) were monitored for 400 to $561 \mathrm{~d}$ (Table 1). One female and 2 male sharks tagged with continuous transmitters (Sharks 10 to 12) were tracked manually for $61.0,51.8$, and $62.8 \mathrm{~h}$, respectively. Signals from those sharks and one other female tagged with a continuous transmitter (Shark 9) were also recorded by a moored receiver for 123 to $212 \mathrm{~d}$. Signals from the 3 female sharks that were tagged with CHAT tags were monitored by a moored receiver for 
99 d. Of the 3 sharks carrying CHAT tags, data were received from Shark 15 for only $9 \mathrm{~d}$ after the tag was deployed. Signals from Sharks 13 and 14 were recorded sporadically up to 29 days after release, but no depth data were transferred from the tags to the $\mathrm{CHAT}$ receiver. Tests conducted on the CHAT receiver near the end of the study indicated that there were communication problems between the CHAT tags and the CHAT receiver. We think the failure of the $2 \mathrm{CHAT}$ tags to report archived data and the failure of the tag from Shark 15 to report additional data was due to equipment malfunction rather than animal behavior.

\section{Site fidelity, activity patterns, and habitat use}

Sharks tagged with coded transmitters (Sharks 1 to 8) were consistently detected within the array each month of the study period with the exception of Sharks $4,6,7, \& 8$, which were detected only sporadically or not at all in 2 or 3 months in spring 2006 (Fig. 2). Signals from all sharks tagged with coded transmitters were recorded an average $\pm \mathrm{SE}$ of $73 \pm 1 \%$ of the total days that sharks were monitored. Sharks tagged with continuous transmitters also demonstrated high site fidelity. Totals of 344,315 , and 362 positional fixes (Sharks 10, 11, and 12, respectively) were recorded during the manual tracking periods that occurred over 64 to $71 \mathrm{~d}$ in the late summer and fall of 2005 (Table 1). The core activity spaces (50\% KUD areas) for these 3 sharks encompassed areas of $0.03,0.15$, and $0.16 \mathrm{~km}^{2}$ (Fig. 3). Home range estimates (sum of all KUD areas calculated) for the 1 female and 2 males tracked manually were 0.20 , 2.20 , and $1.46 \mathrm{~km}^{2}$.

A total of 572188 detections were recorded from the coded tags implanted in prickly sharks (Sharks 1 to 8 ) for the 2 time periods in which the entire VR2 array was deployed (10 Oct 2005 to 12 Feb 2006 and 15 Jun to 12 Sep 2006). The VR2_1 receiver, located at the head of the canyon, recorded the greatest proportion of detections (66\%) during dusk and night hours (17:30 to 06:00 h), from all sharks tagged with coded transmitters. Receivers VR2_2 and VR2_3, which were moored further offshore, recorded the greatest proportions (64 and $54 \%$ ) of detections during the dawn and day hours (06:00 to 17:30 h).

During the nighttime tracking period, the highest proportion of positional fixes obtained from 3 of the continuous tags occurred in the $\mathrm{I}_{\mathrm{M}}$ habitat (each of the 3 sharks $27 \%$ of all signals recorded, Table 2). During the daytime tracking period, the highest proportion of all signals recorded from the 2 male sharks (Sharks 11 and 12) occurred in the $\mathrm{O}_{\mathrm{B}}$ habitat type (34 and $24 \%$ of all signals recorded). The female (Shark 10) carrying a continuous tag resided in the inshore zone, as evidenced by the fact that $89 \%$ of all fixes were obtained in inshore habitats (Fig. 3B). During the day, the greatest proportion of fixes from Shark 10 were obtained in the $I_{B}$ habitats and at night the greatest proportion of detections occurred in the $\mathrm{I}_{\mathrm{M}}$ habitats. This vertical pattern was the same activity pattern as was observed for the 2 male sharks that were manually tracked.

The daily average depths recorded from the continuous transmitters were similar among all 4 sharks carrying continuous transmitters. Mean depths were 53.3 and $45.2 \mathrm{~m}$ for the tagged females (Sharks $9 \& 10$, respectively) and 48.5 and $44.1 \mathrm{~m}$ for the tagged males (Sharks 11 \& 12). However, the mean depth recorded from Shark 9 was significantly different than the other sharks $(F=1.723$, df $=3,91, \mathrm{p}=0.17)$. The average depth anomaly among the 4 sharks was $+12.1 \mathrm{~m}$ from signals recorded during dawn and daylight hours (06:00 to $17: 30 \mathrm{~h}$ ) and $-14.0 \mathrm{~m}$ for the dusk and nighttime hours (17:30 to 06:00 h). The plot of the mean

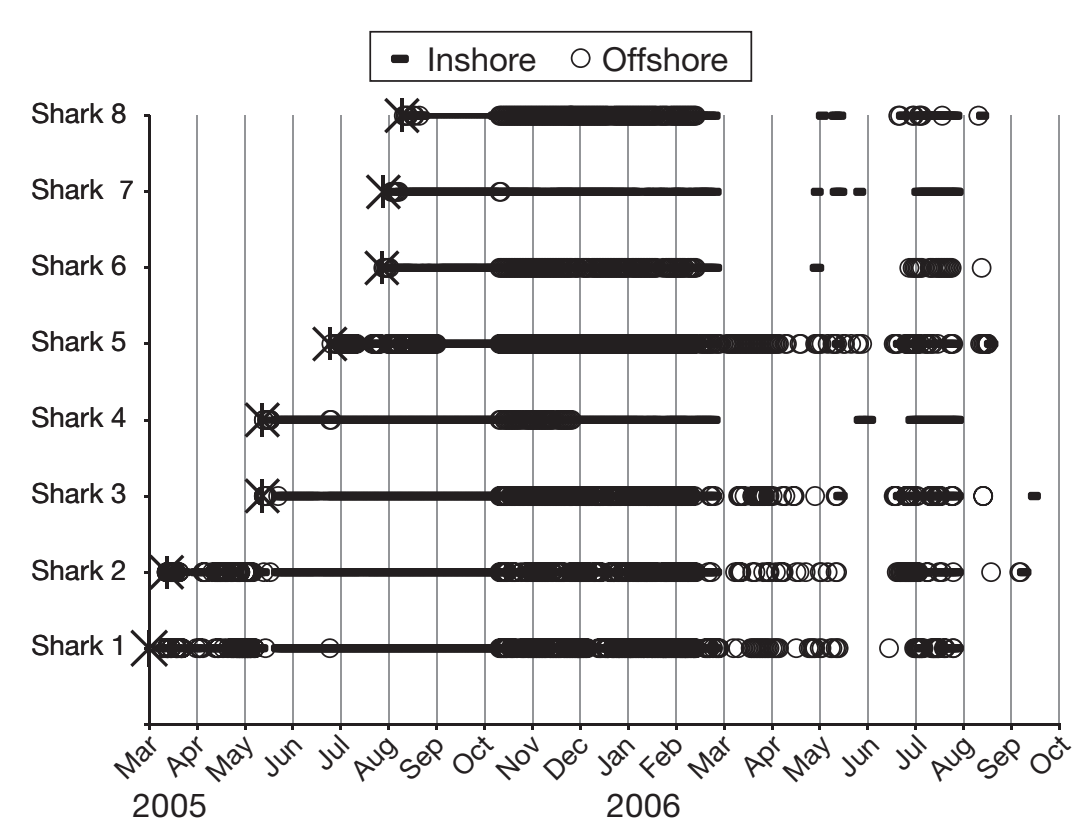

Fig. 2. Echinorhinus cookei. Days in which signals from prickly sharks tagged with V16 coded transmitters were recorded on VR2 receivers moored in the Monterey Canyon. Each tagged shark is identified on the $y$-axis. Asterisks = date each shark was tagged and released. Each symbol along the $x$-axis $=$ a day in which at least 2 signals from a tagged shark were recorded by a receiver. Dashes = signals recorded on a VR2 receiver located in Inshore habitats $(<100 \mathrm{~m}$ depth at the head of the canyon); circles = signals recorded on VR2 receivers located in Offshore habitats (>100 m depth) 


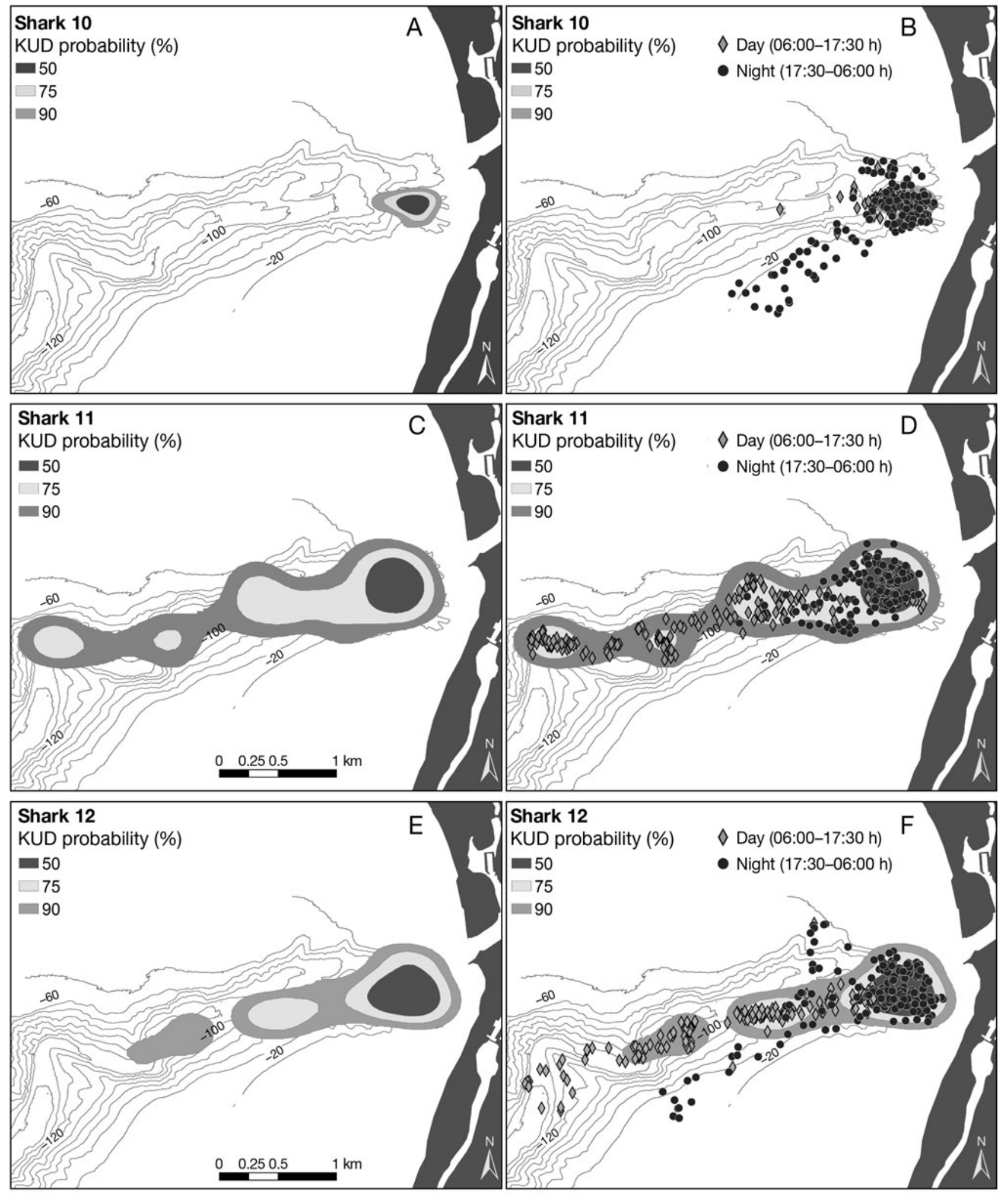

Fig. 3. Echinorhinus cookei. Activity spaces and home ranges of prickly sharks depicted by kernel utilization distributions (KUD) defined by detections of tagged sharks. (A,B) Shark 10, (C,D) Shark 11, and (E,F) Shark 12. (A,C,E) 50, 75, and 90\% KUDs for each shark; $(B, D, F)$ Locations: circles = nighttime $(17: 30-06: 00 \mathrm{~h})$ locations of tagged sharks, and diamonds $=$ daytime (06:00-17:30 h) locations. (B) 344 individual positional fixes, (D) 315 fixes, and (F) 362 fixes 
anomalies for all 4 sharks tagged with continuous transmitters demonstrated a diel activity pattern in which sharks were deeper during day and shallower at night (Fig. 4).

Table 2. Echinorhinus cookei. Summary of habitat use of 3 subadult prickly sharks (see 'Materials and materials study site' for description of habitats). Proportion of total detections spent in each zone is reported for day (06:00$17: 30 \mathrm{~h})$ and night $(17: 30-06: 00 \mathrm{~h})$ periods. Total detections are no. of acoustic detections occurring during manual tracking operations over a 64 to $71 \mathrm{~d}$ time period

\begin{tabular}{|c|c|c|c|c|c|}
\hline & \multicolumn{4}{|c|}{ Proportion of total detections (\%) } & \multirow{3}{*}{$\begin{array}{c}\text { Total } \\
\text { detections } \\
\text { (n) }\end{array}$} \\
\hline & Insh & & Offsh & ore & \\
\hline & $\begin{array}{c}\text { Benthic, } \\
\mathrm{I}_{\mathrm{B}}\end{array}$ & $\begin{array}{c}\text { Mid, } \\
\mathrm{I}_{\mathrm{M}}\end{array}$ & $\begin{array}{c}\text { Benthic, } \\
\mathrm{O}_{\mathrm{B}}\end{array}$ & $\begin{array}{c}\mathrm{Mid}_{,} \\
\mathrm{O}_{\mathrm{M}}\end{array}$ & \\
\hline \multicolumn{6}{|c|}{ Shark 10} \\
\hline Day & 40 & 5 & 0 & 0 & 148 \\
\hline Night & 17 & 27 & 7 & 4 & 180 \\
\hline \multicolumn{6}{|c|}{ Shark 11} \\
\hline Day & 9 & 2 & 34 & 9 & 170 \\
\hline Night & 12 & 27 & 2 & 5 & 142 \\
\hline \multicolumn{6}{|c|}{ Shark 12} \\
\hline Day & 10 & 3 & 24 & 6 & 156 \\
\hline Night & 22 & 27 & 6 & 2 & 201 \\
\hline
\end{tabular}

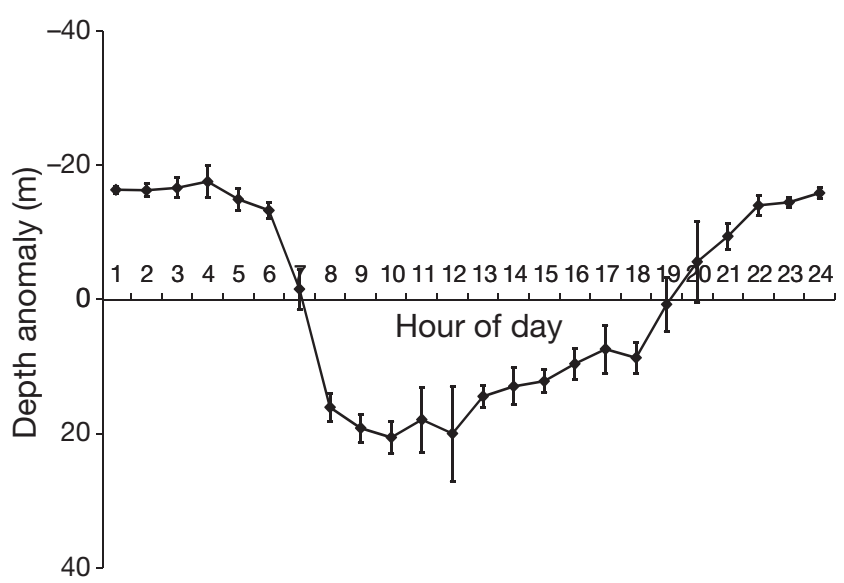

Fig. 4. Echinorhinus cookei. Relative depths of tagged prickly sharks during the day, depicted as hourly anomalies from a shark's overall mean depth. Depth anomaly was calculated by subtracting the difference between the mean depth of a tagged shark in each hour of the day and that shark's overall mean depth. Hourly differences were averaged for all sharks $(\mathrm{n}=4)$ and plotted as mean $\pm \mathrm{SE}$

\section{Rates of movement}

The highest recorded mean \pm SE ROM occurred during dawn for all 3 sharks $(9.5 \pm 1.5,19.5 \pm 2.5$, and $16.4 \pm 3.5 \mathrm{~m} \mathrm{~min}^{-1}$ ). The mean ROM for all sharks combined was highest during dawn $\left(14.7 \pm 1.4 \mathrm{~m} \mathrm{~min}^{-1}\right)$, followed by dusk (10.4 $\pm 1.0 \mathrm{~m} \mathrm{~min}^{-1}$, Table 3$)$. All movements of tagged sharks during dawn were characterized by a directed offshore movement and during dusk by a directed inshore movement.

\section{Archival data}

We analyzed $214 \mathrm{~h}$ of CHAT tag data that were recorded from Shark 15, from 00:29 h on 10 August to 22:29 h on 18 August 2005. The data collected during the first hour after the shark was tagged were discarded to discount the influence of the surgical procedure. When plotted, the data from the CHAT tag portrayed a diel activity pattern in which Shark 15 was deeper during day and shallower at night (Fig. 5); this is consistent with the diel pattern obtained from sharks tagged with continuous transmitters. The average \pm SE depth of Shark 15 for all data gathered during dusk and day (05:30 to $20: 30 \mathrm{~h})$ was $182.9 \pm 3.1 \mathrm{~m}$. This was significantly greater (Student's $t=29.749, \mathrm{p}=0.000$ ) than the average depth during dusk and night (20:30 to 05:30 h), which was $46.4 \pm 2.4 \mathrm{~m}$.

\section{DISCUSSION}

The large spacing between the receivers (lack of overlapping detection ranges) and the loss of moored receivers during some portions of the study period precluded a fine-scale analysis of the data obtained from the coded tags. Nevertheless, subadult prickly sharks in this study clearly occupied the upper reaches of the Monterey Canyon for most of the study period. Sharks carrying coded transmitters exhibited a high degree of site fidelity; most tagged sharks were detected within the receiving array every month during the study period, and all were detected in at least 9 mo. Although there was some indication of a seasonal pattern

Table 3. Echinorhinus cookei. Mean rate of movement (ROM, $\mathrm{m} \mathrm{min}^{-1}$ ) for 3 prickly sharks implanted with continous transmitters and manually tracked. Fastest ROM of each shark was observed during the Dawn tracking period

\begin{tabular}{|lcrrrr|}
\hline Shark & Sex & Day (08:00-17:30 h) & Dusk (17:30-19:30 h) & Night (19:30-06:00 h) & Dawn (06:00-08:00 h) \\
\hline 10 & F & $6.43 \pm 0.71$ & $7.80 \pm 0.96$ & $9.40 \pm 0.58$ & $9.47 \pm 1.48$ \\
11 & M & $9.34 \pm 0.80$ & $17.72 \pm 2.80$ & $8.35 \pm 0.58$ & $19.51 \pm 2.53$ \\
12 & M & $11.21 \pm 0.98$ & $10.40 \pm 1.62$ & $10.10 \pm 0.57$ & $16.38 \pm 3.46$ \\
Combined mean & - & $9.22 \pm 0.51$ & $10.37 \pm 0.97$ & $9.36 \pm 0.33$ & $14.69 \pm 1.42$ \\
\hline
\end{tabular}




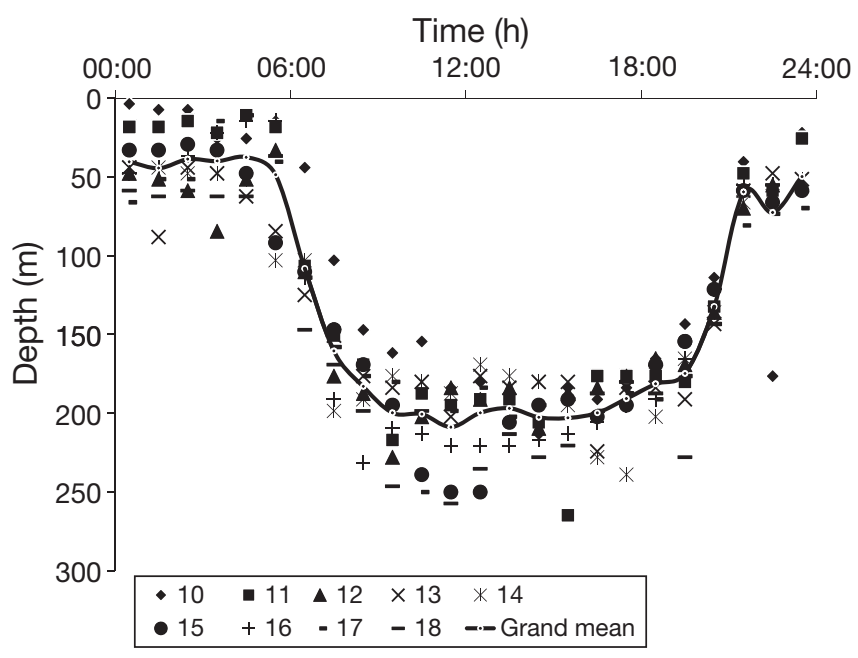

Fig. 5. Echinorhinus cookei. Mean hourly depths of a female prickly shark derived from CHAT archival tag data for a $9 \mathrm{~d}$ period. $x$-axis: time, where 00:00 h represents midnight and 24:00 h represents midnight of the next day. $y$-axis: average hourly depth of tagged Shark 15 (female). Each of the 9 series of data points has a unique symbol to indicate the day on which the data were collected. Each symbol represents the mean depth of the shark for the previous hour

and variation among sharks that was not consistent among males and females, the data obtained from monthly tag detections indicated that subadult prickly sharks frequently occupy the upper reaches of the Monterey Canyon.

This pattern of high site fidelity for extended time periods has also been reported for other large sharks, such the sixgill shark Hexanchus griseus in the Puget Sound (Andrews et al. 2007) and the sevengill shark Notorhynchus cepidus in Humboldt and San Francisco Bays (Ebert 1986, Van Dykhuizen et al. 1998). As with the sixgill and sevengill sharks, the prickly shark is an apex predator. Our results from analyses of the coded transmitters indicated that prickly sharks have a consistent presence in the upper reaches of the Monterey Canyon ecosystem. We speculate that the presence of this large predator likely exerts a strong top-down influence over the community and also could be easily affected by localized natural or anthropogenic perturbations (Wetherbee \& Cortés 2004, Andrews et al. 2007).

All sharks were most often detected in the inshore habitat zone at the head of the canyon at night and in the offshore zone during the day. A strong diel pattern was detected and supported by both manual tracking and monitoring data. Manual tracking of 3 sharks provided evidence of a diel pattern with both a horizontal and vertical component. At night, sharks were inshore at the head of the canyon and were actively swimming in the water column. As the sun began to rise, sharks returned to the seafloor and exhibited a directed movement along the axis of the canyon to discrete areas of refugia located offshore. Tagged sharks remained in these offshore areas throughout the day, and as the sun began to set, moved inshore along the axis of the canyon. This diel pattern of inshore/offshore movement was consistent throughout the study period among all male and female prickly sharks, with one exception. Shark 10, a female, exhibited the same pattern, but in a spatially constrained area. Shark 10 rarely left the inshore habitat at the head of the canyon; however, it resided in a small area with little movement during the day and actively swam inshore and up into the water column at night.

Diel movement patterns have been described for many elasmobranch species (e.g. Nelson et al. 1997, Stokesbury et al. 2005, Hulbert et al. 2006, Andrews et al. 2007). The use of 3 types of acoustic tags (coded, continuous, and archival transmitters) during this study allowed us to characterize both the horizontal and vertical components of the diel movements of prickly sharks. A diel inshore/offshore movement pattern similar to the one we observed was described by Sims et al. $(2001,2005)$ and for the lesser spotted dogfish Scyliorhinus canicula, and seems to be an appropriate model for the prickly shark. The dogfish males studied by Sims et al. (2001) rested in discrete areas in deeper water during the day and made nightly excursions into shallower water where prey was abundant. Females rested in shallower areas segregated from the males during the day and made less frequent excursions at night.

Site-attached fishes, such as this population of prickly shark, may gain an energetic benefit from resting in deeper areas during non-feeding periods while remaining near a highly productive area such as the head of the Monterey Canyon (Genin 2004). In our study, subadult prickly sharks remained in small, centralized areas and moved little during the day. This pattern of a species remaining in a relatively small, centralized, and discrete location within its home range for a large portion of the day or night was first described by Hamilton \& Watt (1970) and was defined as refuging behavior. Refuging has been documented for other elasmobranchs and is often associated with predation avoidance, avoidance of aggression from mature conspecifics, reduction of thermal stress, or energy conservation (McLaughlin \& O'Gower 1971, Klimley 1984, 1987, Holland et al. 1993, Economakis \& Lobel 1998, Sims 2005, Sims et al. 2005). In the case of subadult prickly sharks, it is difficult to determine which factor or combinations of factors are causing this refuging behavior. Future studies are needed to further delineate the reason for this refuging pattern, and to test proposed causal factors affecting the behavior in this population of prickly sharks. 
Manual tracking completed at night was conducted from a research vessel that had a depth sounder with visual display (Furuno Model FCV-582L). This allowed us to observe high-resolution images of the water column during most tracking sessions. During all nighttime tracking sessions, images from the depth sounder indicated the presence of large schools of small fishes. These fish were identified to be primarily anchovies Engraulis mordax and sardines Sardinops sagax, based on the catches of commercial purse seine vessels that were fishing in the area on nights we surveyed. Although we did not collect stomach samples, the increased frequency and range of movements at night indicate that prickly shark movements in the middle of the water column at night are likely associated with feeding on schooling fishes. A study of stomach contents or stable isotopes would help determine if movements we observed are directly related to foraging.

The surface waters above the edges of marine canyons and the shallow waters at the heads of coastal marine canyons are highly productive and serve as feeding grounds for many marine species (Croll et al. 2005). The heads of marine canyons may thus provide higher trophic-level predators, such as deep-water sharks, the opportunity to easily access shallower, energy-rich waters. Subadult prickly sharks tagged in this study exhibited a pronounced inshore-offshore diel movement pattern that was associated with day and night. We used a combination of 3 types of acoustic transmitters and 3 different tracking techniques to clearly delineate a distinct movement of prickly sharks from offshore during the day to inshore at night. Tagged sharks exhibited the highest rates of horizontal movement during crepuscular periods. The head of the canyon was the most important habitat that prickly sharks used within the study area and was used most often during the night, which was likely associated with foraging behavior. Our growing understanding of ecosystem interactions and community ecology highlights the necessity of gathering both long-term and high-frequency movement data to help understand the role of large predators in an ecosystem (Levin 1992). Both types of spatial data are critical in characterizing the role and strength of interactions among species, and thus are necessary components of successful ecosystem management (Magnuson et al. 2006).

Acknowledgments. Our enormous thanks to the many prickly shark tag team volunteers without whom this study could not have been completed. Special thanks to D. Kline whose presence on fishing trips was an important part of the success of this study. Bathymetry data used in this study were acquired, processed, archived, and distributed by the Seafloor Mapping Laboratory of California State University Monterey Bay. Thanks to J. Douglas, S. Hansen, and D. Steller for their help with logistics and overall support of the long hours of field work involved. Thanks to G. Caillet, J. Harvey, and R. Larson, and the anonymous reviewers for their comments which greatly improved the manuscript. Funding for this study was provided by the University of California Sea Grant Program, Monterey Bay Aquarium, Packard Foundation, American Academy of Underwater Sciences, John H. Martin Scholarship, and the Earl H. and Ethel M. Meyers Oceanographic and Marine Biological Trust.

\section{LITERATURE CITED}

Anderson ME, Cailliet GM, Antrim BS (1979) Notes on some uncommon deep-sea fishes from the Monterey Bay area, California. Calif Fish Game 65:256-264

Andrew NL, Mapstone BD (1987) Sampling and the description of spatial pattern in marine ecology. Oceanogr Mar Biol Annu Rev 35:39-90

Andrews KS, Levin PS, Katz SL, Farrer D, Gallucci VF, Bargmann G (2007) Acoustic monitoring of sixgill shark movements in Puget Sound: evidence for localized movement. Can J Zool 85:1136-1142

Bascompte J, Melian CJ, Sala E (2005) Interaction strength combinations and the overfishing of a marine food web. Proc Natl Acad Sci USA 102:5443-5447

Beyer HL (2004) Hawth's analysis tools for ArcGIS. www. spatialecology.com/htools (accessed 1 Jan 2006)

Carr MH, Anderson TW, Hixon MA (2002) Biodiversity, population regulation, and the stability of coral-reef fish communities. Proc Natl Acad Sci USA 99:11241-11245

Compagno LJV (1984) Sharks of the world: an annotated and illustrated bibliography of species known to date. FAO species catalogue No. 4, Parts 1 and 2. FAO, Rome

Crane NL, Heine JN (1992) Observations of the prickly shark (Echinorhinus cookei) in Monterey Bay, California. Calif Fish Game 78:166-168

Croll DA, Marinovic B, Benson S, Chavez FP, Black N, Ternullo R, Tershy BR (2005) From wind to whales: trophic links in a coastal upwelling system. Mar Ecol Prog Ser 289: $117-130$

Crow GL, Lowe CG, Wetherbee BM (1996) Shark records from longline fishing programs in Hawai'i with commentary on Pacific Ocean distributions. Pac Sci 50:382-392

Crowder L, Norse E (2008) Essential ecological insights for marine ecosystem-based management and marine spatial planning. Mar Policy 32:772-778

Ebert D (1986) Aspects on the biology of hexanchid sharks along the California coast. In: Uyeno T, Arai R, Taniuchi T, Matsuura K (eds) Indo-Pacific fish biology. Proc 2nd Int Conf on Indo-Pacific Fishes, Tokyo (Japan), 29 Jul-Aug 3, 1985. Ichthyological Society of Japan, Tokyo, p 437-449

Ebert DA (2003) Sharks, rays and chimaeras of California. University of California Press, Berkley, CA, p 60-62

Economakis AE, Lobel PS (1998) Aggregation behavior of the grey reef shark, Carcharhinus amblyrhynchos, at Johnston Atoll, Central Pacific Ocean. Environ Biol Fishes 51: $129-139$

Estes JA, Tinker MT, William TM, Doak DF (1998) Killer whale predation on sea otters linking oceanic and nearshore ecosystems. Science 282:473-476

Garrick JAF (1960) Studies of New Zealand elasmobranchii, part 10. The genus Echinorhinus, with an account of a second species, E. cookei Pietschmann, 1928, from New Zealand waters. Trans R Soc NZ 88:105-117

Garrick JAF, Moreland JM (1968) Notes on a bramble shark, Echinorhinus cookei, from Cook Strait, New Zealand. Rec Dom Mus (Wellingt) 6:133-139 
Genin A (2004) Bio-physical coupling in the formation of zooplankton and fish aggregations over abrupt topographies. J Mar Syst 50:3-20

Hamilton WJ, Watt KE (1970) Refuging. Annu Rev Ecol Syst $1: 263-287$

Hatcher G (1997) ArcNav real-time extension (V1.0) for ArcView (V3.0a). www.mbari.org/data/gis/ArcNavVersion1. htm (accessed 15 March 2005)

Holland KN, Wetherbee BM, Peterson JD, Lowe CG (1993) Movements and distribution of hammerhead shark pups on their natal grounds. Copeia 1993(2):495-502

Hulbert LB, Sigler MF, Lunsford CR (2006) Depth and movement behavior of the Pacific sleeper shark in the northeast Pacific Ocean. J Fish Biol 69:406-425

Klimley AP (1984) Diel movement patterns of the scalloped hammerhead shark (Sphyrna lewini) in relation to El Bajo Espiritu Santo: a refuging central-position social system. Behav Ecol Sociobiol 15:45-54

Klimley AP (1987) The determinants of sexual segregation in the scalloped hammerhead, Sphyrna lewini. Environ Biol Fishes 18:27-40

Kobayashi H (1986) Studies of deep-sea sharks in Kumanonada region. Bull Fac Fish Mie Univ 13:25-133

Levin SA (1992) The problem of pattern and scale in ecology. Ecology 73:1943-1967

Magnuson JJ Jr, Cowan JH, Crowder LB, Dallmeyer DG and others (2006) Dynamic changes in marine ecosystems: fishing, food webs, and future options. National Academy Press, Washington, DC

McLaughlin RH, O'Gower AK (1971) Life history of underwater activities of a heterodont shark. Ecol Monogr 41: 271-289

McLeod KL, Lubchenco J, Palumbi SR, Rosenberg AA (2005) Scientific consensus statement on marine ecosystembased management. Communication Partnership for Science and the Sea (COMPASS). Available at: http:// compassonline.org/pdf_files/EBM_Consensus_Statement_ v12.pdf

Melendez CR, Menses RS (1986) Tiburones del talud continental entre Arica $\left(18^{\circ} 25^{\prime} \mathrm{S}\right)$ e Isla Mocha (38 $\left.15^{\prime} \mathrm{S}\right)$ Chile. Biota 1:118

Myers RA, Baum JK, Shepherd D, Powers SP, Peterson CH (2007) Cascading effects of the loss of apex predatory sharks from a coastal ocean. Science 315:1846-1850

Nelson D, McKibben JN, Strong WR, Lowe CG, Sisneros JA, Schoreder DM, Lavenberg RG (1997) An acoustic tracking of a megamouth shark, Megachasma pelagios: a crepuscular vertical migratory. Environ Biol Fishes 49:389-399

Pietschmann V (1930) Remarks on Pacific Fishes. Bull Bernice P Bishop Mus 73:1-6

Editorial responsibility: Steven Morgan,

Bodega Bay, California, USA
Reisewitz SE, Estes JA, Simenstad CA (2006) Indirect food web interactions: sea otters and kelp forest fishes in the Aleutian archipelago. Oecologia 146:623-631

Shears NI, Babcock RI (2002) Marine reserves demonstrate top-down control of community structure on temperate reefs. Oecologia 132:131-142

Sims DW (2005) Differences in habitat selection and reproductive strategies of male and female sharks. In: Ruckstuhl KE, Neuhaus P (eds) Sexual segregation in vertebrates. Cambridge University Press, Cambridge, p $127-147$

Sims DW, Nash JP, Morritt D (2001) Movements and activity of male and female dogfish in a tidal sea lough: alternative behavioral strategies and apparent sexual segregation. Mar Biol 139:1165-1175

Sims DW, Southall EJ, Wearmouth VJ, Hutchinson N, Budd CG, Morrit D (2005) Refuging behaviour in the nursehound Scyliorhinus stellaris (Chondrichthys: Elasmobranchii): preliminary evidence from acoustic telemetry. J Mar Biol Assoc UK 85:1137-1140

Smith DP, Kvitek R, Iamapietro PJ, Wong K (2007) Twentynine months of geomorphic change in upper Monterey Canyon (2002-2005). Mar Geol 236:79-94

Stokesbury MJW, Harvey-Clark C, Gallant J, Block BB, Myers RA (2005) Movement and environmental preferences of Greenland shark (Somniosus microcephalus) electronically tagged in the St. Lawrence Estuary, Canada. Mar Biol 148:159-165

Van Dykhuizen G, Mollet HF, Ezcurra JM (1998) Homing behavior of a sevengill shark released from the Monterey Bay Aquarium. Calif Fish Game 84:180-181

Varoujean DH (1972) Systematics of the genus Echinorhinus Blainville, based on a study of the prickly shark, Echinorhinus cookei Peitschmann. MS thesis, Fresno State College, Fresno, CA

Wetherbee BM, Cortés E (2004) Food consumption and feeding habits. In: Carrier JC, Musik JA, Heithaus MR (eds) Biology of sharks and their relatives. CRC Press, Boca Raton, FL, p 225-246

Worton BJ (1987) A review of models of home range for animal movement. Ecol Model 38:277-298

Worton BJ (1989) Kernel methods for estimating the utilization distribution in home ranges studies. Ecology 70 : $164-168$

Zeidberg LD, Robison BH (2007) Invasive range expansion by the Humboldt squid, Dosidigus gigas, in the eastern North Pacific. Proc Natl Acad Sci USA 104:12948-12950

> Zeller DC (1997) Home range and activity patterns of the coral trout Plectorpomus leopardus (Serranidae). Mar Ecol Prog Ser 154:65-77

Submitted: September 8, 2008; Accepted: April 20, 2009

Proofs received from author(s): June 20, 2009 